\title{
Bazı Ses Olaylarında Bulaşma Sebebi Olarak Arap Alfabesi
}

\section{Arabic Alphabet as the Cause of Contamination in Some Phonetic Events}

\author{
İhsan Sabri ÇEBI ${ }^{1}$
}

1Sorumlu yazar/Corresponding author: İhsan Sabri Çebi (Dr. Öğr. Üyesi), Namık Kemal Üniversitesi, Fen-Edebiyat Fakültesi, Türk Dili ve Edebiyatı Bölümü, Tekirdağ, Türkiye. E-posta: iscebi@nku.edu.tr

ORCID: 0000-0001-8889-0025

Başvuru/Submitted: 20.03 .2019 Revizyon Talebi/Revision Requested: 14.10.2019

Son Revizyon/Last Revision Received: 05.11.2019

Kabul/Accepted: 10.11.2019

Online Yayın/Published Online: 12.06.2020

Atıf/Citation: Cebi, Ihsan Sabri. "Bazı Ses Olaylarında Bulaşma Sebebi Olarak Arap Alfabesi." Türkiyat Mecmuasi-Journal of Turkology 30, 1 (2020): 81-95.

https://doi.org/10.26650/iuturkiyat.706876

\section{öz}

Dilin ses yapısında meydana gelen değişmelere ses olayı denir. Ses olayının sebeplerinden biri de, bir kelime veya şeklin başka bir kelime veya şekli etkileyerek ortak özelliklere sahip başka şeklin oluşması demek olan bulaşmadır. Türkçenin Arap alfabesi ile yazıldığı dönemlerinde Arap alfabesindeki "vav" ve "ya" harflerinin Türkçedeki hem ünlü hem de ünsüz bazı sesleri karşılaması birtakım Arapça ve Farsça kelimelerde farklı okumalara sebep olmuştur. Yani bazı kelimelerde ünlü okunması gereken "ya" harfi ünsüz; bazı kelimelerde ünsüz okunması gereken "vav" ve "ya" harfleri ünlü okunmuşlardır. Bu farklı okumalar sonucunda bazı kelimeler kaynak dildeki karşılıklarından başka bir şekle dönüşmüşlerdir. Arap alfabesinde olmayan " $g$ " ve "damak n'si" gibi sesler, Arap harfli Türk alfabesinde, Fars alfabesinden alınan "kâf-i Farisî" ve Türkler tarafından oluşturulan “kâf-i nûnî"ile karşılanmışlardır. Ancak bu sesler el yazması eserlerde çok zaman kolaylık sebebiyle Arabî kef ile yazılmışlardır. Bazı Arap lehçelerine girmiş olan ve bünyesinde bu sesleri barındıran birtakım Türkçe kelimelerde, bahsedilen seslerin Arap alfabesindeki kef harfiyle yazılmasından dolayı farklı okunmaları söz konusudur. Yine Arap alfabesindeki hareke sistemi sebebiyle de bazı kelimelerde ses olayları ortaya çıkmıştır. Aynı harflerle yazılan bazı kelimelerin farklı harekelenmesi sonucunda eş anlamlı farklı kelimeler ortaya çıkmıştır. Aslında farklı sebepler ile ses olayı geçirmiş olan tespit ettiğimiz bazı kelimelerde ortaya çıkan bütün ses olaylarının yönünü belirleyen şey, bulaşmadır. Bu olaylardaki bulaşma sebebi ise Arap alfabesi, daha genel bir ifade ile yazıdır. Bu da ses olaylarının önce konuşma dilinde meydana gelmesi genel karakterinden farklı olarak yazının da ses olaylarına sebep olması gibi bir tespiti ortaya koymaktadır. Yazımızda, Eski Anadolu Türkçesi dönemine ait bazı yazma eserlerde tespit ettiğimiz bu tür ses olayı geçirmiş örneklere yer verdik. Anahtar kelimeler: Bulaşma, ses olayları, ses değişmeleri, Arap alfabesi, Arap harfli Türk alfabesi, Türk dili

\section{ABSTRACT}

Changes which occur in the phonetic structure of a language are called phonetic events. One of the reasons for phonetic change is contamination in which a word or form influences another word or form and a different form with common features arises. In earlier periods when Turkish was written in Arabic letters, the fact that the Arabic letters "vav" and " $y a$ " corresponded to both vowel and consonant phonemes caused there to be some different pronunciations in 
Arabic and Persian words. In other words, the letter "ya" which is expected to be pronounced as a vowel is pronounced as a consonant, and the letters " $v a v$ " and " $y a$ " are pronounced as vowels although they are expected to be pronounced as consonants. As a result of these variant pronunciations, some words evolved into forms that are different from the corresponding words in their original language. Phonemes such as " $g$ " and "nasal $n$ " which are not found in the Arabic alphabet are counterbalanced in the Ottoman alphabet with "kâf-i Farisi”" borrowed from the Persian alphabet and "kâf-i nûnî" which Turks developed. But these phonemes were written with Arabic kef in manuscripts due to greater ease of writing. In some Turkish words which include these phonemes and which are used in some Arabic dialects, different pronunciations exist due to the fact that the mentioned phonemes in the Arabic alphabets are written with the letter kef. The reason for these phonetic events which are based on contamination is the system of vowel points in the Arabic alphabet. As some words written with the same letters were developed with different vowel points, synonymous words came into existence. It is in fact contamination which determines the direction of all phonetic events that emerge in these words undergoing phonetic events through different reasons. The reason for contamination in those events is the Arabic alphabet, that is, writing in more general terms. The fact that phonetic events arise firstly in spoken language indicates that it is not the typical characteristic of writing to cause phonetic events although this is possible. Examples that belong to the period of Old Anatolian Turkish and that undergo this kind of phonetic event are given in the study.

Keywords: Contamination, phonetic events, phonetic changes, Arabic alphabet, Turkish alphabet with Arabic letters, Turkish language

\section{EXTENDED ABSTRACT}

Changes which occur in the phonetic structure of a language are called phonetic events. One of the reasons for phonetic change is contamination in which a word or form influences another word or form and a different form with common features arises. In earlier periods when Turkish was written in Arabic letters, the fact that the Arabic letters " $v a v$ " and " $y a$ " corresponded to both vowel and consonant phonemes caused differences of pronunciation between Arabic and Persian words. For example the letter ya (ي) in some Arabic and Persian words is expected to be pronounced as a consonant but in fact is pronounced as a vowel. Likewise, the letter $v a v(g)$ is expected to be pronounced as a consonant but is pronounced as a vowel. As a result of these variant pronunciations, some words transform into another form that is different from their corresponding words in the original language. When we consider some identified examples, we see that this phonetic change began to occur when the Oghuz accent became a written language in the period of Old Anatolian Turkish. Some examples such as “hayrlı > hırlı (خيرلي); hayrsız > hırsız (خيرسز); na'leyn > nalın (نعلين); Züleyha >

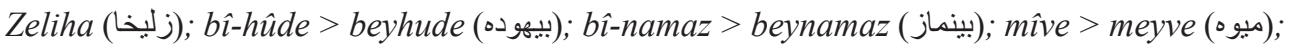

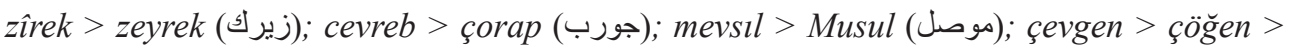
coven (جوكن); sevsen > sûsen (سوسن); gevher > güher (كو هر ( phonetic change, began to be used in written language. However the examples below, which we identified in a previous study and which underwent the same changes, were observed to remain in the spoken language instead of being used in the written language. A number of examples belong to the period of Old Anatolian Turkish and are as follows: şeyh > şlh (نَيَخ); peydâ > bîza, pîza (بيذا); seyl > sîl (سيل); bevl > bôl bûl (بول); nevrûz > nôruz نوروز) ); edviyye > edüyye (ادوية); Nevfel > Nûfil (نوفل). 
We identified some phonetic changes in the Cairo accent of Arabic on this basis: mûlid

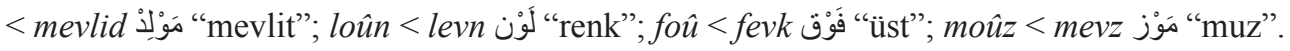

Phonemes such as " $g$ " and "nasal $n$ " which are not found in the Arabic alphabet are counterbalanced in the Ottoman alphabet with " $k \hat{a} f-i$ Farisî" borrowed from the Persian alphabet and "kâf-i nûn in manuscripts due to greater ease of writing. In some Turkish words which include these phonemes and which have been used in some Arabic dialects, different pronunciations exist due to the fact that the mentioned phonemes in Arabic alphabets are written with the letter kef. Some examples that have been transformed in that way are as follows: beg > bek (بح)); yegen > yeken (يكن); legen > lakan (لكن); biñbaşı > bikbâşî (بكاشن); yeñiçeri > inkişârî (يخي جري).

Some examples of contamination that we identified are very striking and need special mention. The reason for these phonetic events which are based on contamination is the system of vowel points in the Arabic alphabet. As some words written with the same letters are developed with different vowel points, synonymous words came into existence. New words emerging in that manner have completely matching concepts in semantic terms: alaca ibik $>$ elçi ibik (الجها: الجك) ip avadanlig > ip odunlug (ايب اودنلغي).

It is in fact contamination which determines the direction of all phonetic events that emerge in these words undergoing phonetic events for different reasons. The reason for contamination in those events is the Arabic alphabet, that is, writing in more general terms. The fact that phonetic events arise firstly in spoken language indicates that it is not a typical characteristic of writing to cause phonetic events although this is possible.

The fact that contamination causes similar phonetic events in both Arabic dialects and in Persian makes the situation interesting. It is clear that the tendency to take the easy way out is the most typical cause of phonetic events and this plays a great role in these events.

Examples that belong to the period of Old Anatolian Turkish and that undergo this kind of phonetic event are given in the study. It is anticipated that many examples will be determined as a result of reviewing works on vowel points that belong to the above-mentioned period. These examples will contribute to the etymological dictionary of language. 


\section{Giriş}

Canlı bir varlık olan dil zaman içinde değişerek gelişir. Milletlerin zaman içinde maruz kaldıkları coğrafî ve kültürel değişiklikler ile kültürler arası ilişkiler gibi sosyal sebepler bu gelişim sürecinde dilin iç ve dış yapısında bir takım değişikliklere yol açar.

Dilin ses yapısında meydana gelen değişikliklere 'ses olayı' denir. Türkçede karşılaştığımız ses olaylarını düşme, değişme, benzeşme, yer değiştirme, türeme gibi genel başlıklar altında toplamak mümkündür. ${ }^{1}$

Ercilasun ses olaylarının sebeplerini a) Dilin ses özellikleri, b) Başka seslerin tesiri, c) Vurgu, d) Zayıf sesler, e) Telaffuz güçlüğü ve tenafür, f) Başka kelime ve gramer şekillerinin tesiri, g) Komşu dil, lehçe ve şivelerin tesiri, h) Bazı ses olayları, şeklinde sıraladıktan sonra, bütün bu sebepleri daha genel bir başlık altında toplamanın mümkün olduğunu, bunun da dilbiliminde 'en az çaba kanunu' olarak adlandırılan, insanların konuşurken kolaya kaçma eğilimi olduğunu söyler. ${ }^{2}$

Karaağaç ise, bu sebepleri 1. Irkın etkisi, 2. Coğrafyanın etkisi, 3. En az çaba ve en çok çaba etkisi, 4. Çocuklara verilen ana dili eğitimi, 5. Sosyal ve siyasi etkenler, 6. Alt katman etkisi, 7. Üst katman etkisi, 8. Örneksemelerin etkisi, 9. Yazım kurallarının etkisi, şeklinde sıralar. ${ }^{3}$

Ses olaylarının genel karakteristiği bunların önce konuşma dilinde meydana gelmesidir. Konuşma diline göre daha muhafazakâr olan yazı dili bu ses olaylarının bir kısmını kabul eder. Bazı ses olayları ise bazı bölgelere ait ağız özellikleri olarak kalır. ${ }^{4}$

Yazının ses olaylarına etkisi var mıdır? Yazının ses değişmelerini frenlediği, yavaşlattığı bilinen bir olgudur; ancak yazının ses olaylarına sebep olması ile ilgili şimdiye kadar bizim yazdığımız bir yazı dışında müstakil bir çalışmaya rastlamadık. ${ }^{5}$ Ses olaylarının yukarıda da belirttiğimiz gibi genel karakteri, ses ile alakalı olmasıdır. Seslerin yazı dilindeki karşılıkları olan işaretlere harf; bunların belli bir sıraya konmuş topluluğuna alfabe denir. Yani ses, tabi olunan; harf veya alfabe ise tabi olandır. Bir dilin sesleri, o dilin tarihî süreci içinde değişik işaretler yani alfabelerle gösterilebilir. Bir alfabede o dildeki bazı sesleri karşılayacak harflerin tamamı bulunmayabilir. Bu gibi durumlarda ya başka alfabelerden bazı harfler alınır ya da o alfabenin bazı harflerinden uygun harfler türetilir. Arap alfabesinde /ç, $j, g, p /$ seslerini karşılayan harfler bulunmadığından Osmanlı alfabesinde bu sesler Fars alfabesinden alınma bazı harflerle karşılanmıştır. Farsçada ve Arapçada bulunmayan Türkçeye ait "damak n'si" için de Arap alfabesindeki "kef” harfinden türetilmiş bir harf kullanılmıştır. Edebî dilde her ses için ayrı birer harf olmayıp bazı sesler yaklaşık değerleriyle karşılanır. Bundan dolayıdır ki ses olaylarının tamamını yazılı kaynaklardan takip etmek mümkün olmamaktadır. Çünkü

\footnotetext{
Muharrem Ergin, Türk Dil Bilgisi, (İstanbul: Bayrak Yayınları, 2013), 50-54

Ahmet Bican Ercilasun, Üniversiteler İçin Türk Dili Dersleri, (Ankara: Yök Yayınları, 1992), 76-77.

Günay Karaağaç, Türkçenin Ses Bilgisi, (İstanbul: Kesit Yayınları, 2010), 53-61.

Muharrem Ergin, Türk Dil Bilgisi, 54.

İhsan Sabri Çebi, "Yabancı Kökenli Bazı Kelimelerde Ses Değişmeleri Üzerine", Türk Dili Dil ve Edebiyat Dergisi, 547, (1997), 15-17.
} 
harfler sesleri kabiliyetleri nispetinde karşılar. Mesela Türkçenin kapalı e sesi için Eski Anadolu Türkçesi devresinde bazen Arap alfabesindeki ya (ي) harfinin, bazen de harekelerden üstün veya esre işaretinin, günümüzde ise sadece normal $e$ harfinin kullanılması gibi durumlar yazı dilinin bu sesin gerçek değerinin anlaşılmasına yardımcı olmadığını ortaya koymaktadır..

\section{Bulașma (analogie)}

Dillerde bulaşma, örnekseme, kırmalaşma, analoji gibi değişik terimlerle anılan ve dil olaylarının birçoğunda etkili olan bir eğilim vardır. Bulaşma, bir ögenin başka bir ögeyi etkileyerek her ikisinin de birtakım özelliklerini taşıyan bir başka ögenin oluşmasına yol açması demektir. ${ }^{6}$ Bu yazıda önce genel olarak bulaşma terimini açıklayacak, daha sonra bunun seslerle ilgisine değineceğiz.

Böler, bir bildirisinde bulaşma hakkında detaylı bir bilgi verdikten sonra Muharrem Ergin'in Türk Dil Bilgisi ve Zeynep Korkmaz’ın Türk Dili Üzerine Araştırmalar adlı eserinde yer alan makaleler başta olmak üzere kimi dil bilgisi çalışmalarında "karıştırılma, yanlış çözümleme, yanlış hece bölünmesi” gibi ifadelerle açıklanan bazı örnekleri ele alarak bunların aslında bulaşma (contamination) olarak değerlendirilmesi gerektiğini söyler. Daha sonra bulaşma örneği olduğunu öne sürdüğü bazı yapım ve çekim eklerini inceler. ${ }^{7}$

Tekrara düşmemek için bu ekler içerisinden sadece bir örnek üzerinde durup yazımızın asıl konusu olan örnekleri inceleyeceğiz.

Üleştirme sayı isimleri yapan $\left\{{ }_{S} A r\right\}$ ekindeki /ş/ sesi bazı yayınlarda ünsüz yardımcı sesler içinde gösterilmektedir. Ancak saha ile ilgili herkesin bildiği gibi bu ekte ortaya çıkan $/$ ş/ sesi yardımcı ses değildir. Asıl sayı isimlerine eklenerek üleştirme sayı isimleri yapan $\{+A r\}$ $\left\{{ }_{{ }_{S}} A r\right\}$ eki Eski Türkçede ünsüzlerden sonra $\{+A r\}$, ünlülerden sonra $\{+r A r\}$ şeklindedir. Muharrem Ergin, Eski Türkçede ünlülerden sonra $\{+r A r\}$ şeklinde gelen ekin baştaki ünsüzü $\mid r /$ 'nin bir+er üleştirme sayı isminin bi+rer şeklinde hecelenmesi ile ortaya çıktığını, daha

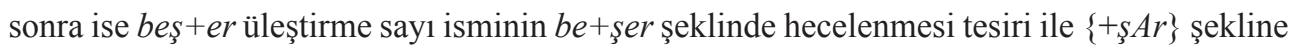
dönüştüğünü söyler. ${ }^{8}$

Ercilasun, Türkçenin yardımcı seslerini incelediği makalesinde bu eki aynı şekilde değerlendirerek $\left\{{ }_{\text {ş }} A r\right\}$ 'daki ş'nin ünlü çatışmasını ortadan kaldırmak için türemiş bir ses olmadığını beş+er'in etkisiyle ortaya çıkan bir bulaşma olduğunu belirtir. ${ }^{9}$

Bulaşma hadisesine ait Ercilasun tarafından verilen ilgi çekici bir örnek de destan kahramanı Oğuz Kağan 'ın ismi ile alakalıdır. Ercilasun aslında öküz yani boğa olan destan kahramanının

6 Berke Vardar, Dilbilim ve Dilbilgisi Terimleri Sözlüğ̈̈, (Ankara: TDK Yayınları, 1980), 45.

7 Tuncay Böler, 'Dilbilgisi Çalışmalarında 'Karışma, Karıştırılma, Yanlış Hece Bölünmesi, Yanlış Çözümleme' Gibi İfadelerle Açıklanan Bulaşma (Contamination) Örnekleri Üzerine, (BILLMES 2017), I. Uluslararası Bilimsel ve Mesleki Çalı̧̧malar Sempozyumu, 2017, 915-914.

8 Muharrem Ergin, Türk Dil Bilgisi, 170.

9 Ahmet Bican Ercilasun, "Türkiye Türkçesinde Yardımcı Ses”, Türk Dili Dil ve Edebiyat Dergisi, (Eylül 2000), $585,2000 / 2,221$. 
isminin boy adı olan $o \breve{g} u z<o k+u z$ 'dan bulaşma ile ortaya çıktığını ifade eder. ${ }^{10}$

Bulaşma ile ilgili kapsamlı bir çalışma Mehmet Kara tarafından yapılmıştır. Kara "Ayrı Düşmüş Kelimeler" adını verdiği eserinde Türkçe asıllı ve alıntı kelimelerde rastlanılan bulaşma örneklerini meydana geliş şekilleriyle birlikte detaylı olarak incelemiştir. ${ }^{11}$

Asıl konumuza geçmeden önce bulaşma ile ilgili iki ilginç örnek üzerinde durmak istiyoruz. Bunlardan biri yeni bir kelime olup henüz sözlüklere girmemiştir. Daha çok devre mülk aidatı için kullanılmaya başlanan bu kelime yıldattır. Bu kelime “aidat”tan bulaşma yoluyla ortaya çıkmıştır. Arapça âid kelimesinin çoğulu aidat Türkçede galat olarak tekil kullanılır. Bu kelime Türkçe Sözlük’te 1. Dernek, kuruluş, kulüp üyelerinin belli sürelerde, belli miktarlarda ödedikleri para, ödenti. 2. Bir hizmet karşılığı sürekli ve düzenli ödenen para. 3. Kesenek, olarak açıklanmaktadır. ${ }^{12}$

Aidat, aylık ödenen bir para anlamında olmadığı hâlde genellikle aylık ödendiği için halk tarafından sanki aylık ödenen bir paraymış gibi algılanmaktadır. Ayrıca Türkçenin ses özelliklerine aykırı olan diftong hadisesi sebebiyle iki ünlü arasında ses türemesiyle âyidat olarak söylenir. Bünyesindeki uzun ünlü ve Türkçe kelimelerde orta hecenin vurgu bakımından zayıf olması gibi iki sebepten dolayı ilk hecesi vurgulu aydat şeklinde söyleyiş kazanarak mana olarak da bir yanlış algı oluşmasına sebep olmuştur. Bu yüzden aylık ödenen ödenti ay+dat ise yıllık ödenen ödenti de $y \iota l+d a t$ olmalıdır düşüncesiyle bulaşma yoluyla dil hazinemize böyle bir kelime kazandırılmıştır.

Diğer örnek ise halk dilinde diyanet kelimesinin göçüşme yoluyla ortaya çıkmış şekli olan dinayettir. Bu kelimede ortaya çıkan göçüşme Türkçe ses sistemine aykırı bir şekilde ortaya çıkmıştır. Çünkü ses olaylarının sebeplerinin en önemlisi olan kolaya kaçma eğilimi bu ses olayında görülmemektedir. Diyanetin söylenişi dinâyetten daha kolaydır. O halde bu kelime niçin böyle bir ses olayı geçirmiştir? Bizce bunun sebebi din kelimesinin bulaşma yoluyla diyaneti dinâyete çevirmesidir. Bu ses olayı ile ilgili çok ilgi çekici bir durum ise dinâyet kelimesinin Ahmed-i Dâî'nin XIV. yüzyılda yazdığı Kitâbü't-ta'bîr' in bilinen iki nüshasından biri olan Atatürk Kitaplığı nüshasında geçmesidir: “dināyet" örneğinin görülmesi, din dili Arapçanın günümüze oranla daha çok tesiri ile açıklanabilir.

\section{Ses Olaylarında Bulaşma Sebebi Olarak Arap Alfabesi}

Bazı yabancı asıllı kelimelerde ses olaylarını yönlendiren, bulaşmadır. Bulaşma sebebi ise Arap alfabesidir. Daha genel bir ifade ile yazıdır. Bu durum ise ses olaylarının genel karakteri olan önce konuşma dilinde meydana gelip bunların bir kısmının sonradan yazı diline geçmesi eğilimine aykırıdır.

10 Ahmet Bican Ercilasun, “Oğuz Adının Etimolojisi”, Oğuzlar: Dilleri, Tarihleri ve Kültürleri, 5. Uluslararası Türkiyat Araştırmaları Sempozyumu, Ankara: 2015, 15-20.

11 Mehmet Kara, Ayrı Düşmüş Kelimeler, (İstanbul: Kesit Yayınları, 2011).

12 Türkçe Sözlük, (Ankara: TDK Yayınları, 2011), 57.

13 Ahmed-i Dâî, Kitâbü't-ta' bîr, Atatürk Kitaplığı (İstanbul Belediye Kütüphanesi), Muallim Cevdet, Nr. O.26, 39a/10. 
Bu konuyla ilgili ilk yazımızı, sınırlı sayıda örnekten oluşan bir makale hâlinde, yayımlamıştık. Söz konusu makalede hırl, hırsız, nalın, şıh, beyhude ve beynamaz kelimelerinin bünyelerinde bulunan Arap alfabesindeki ya (ي) harfinin farklı okunmasından kaynaklanan ses olayına

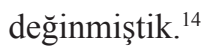

Türk Dil Kurumu tarafından hazırlanan Türkiye Türkçesinin Tarihsel Sözlüğü Projesi çerçevesinde fişlenmek üzere tarafımıza verilen Ahmed-i Dai'nin Kitâbü 't-ta 'bîr adlı eserinde ve Milli Eğitim Bakanlığı görevlendirmesiyle Türkçe dersleri vermek üzere bulunduğumuz Kahire'de Arapçanın Mısır lehçesinde dikkat çekici yeni örnekler tespit etme imkânı bulduk. Bu örneklerde 1997 yılında yayımlamış olduğumuz makaledeki düşünceleri pekiştiren bazı ses olaylarına şahitlik edilmiştir. Kahire'de 1998 yılında düzenlenen ve sonrasında bildiri kitabının da yayınlandığg bir uluslararası sempozyuma bu örneklerden hareketle “Arap Alfabesindeki (ب) Marflerinin Osmanlıcadaki Bazı Arapça ve Farsça; Osmanlı

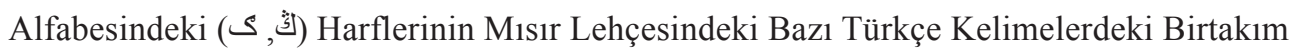
Ses Olaylarındaki Rolü” adlı bir bildiri ile katılmıştık. Bu bildiride, Türkçeye Arapça ve Farsçadan; Arapçaya da Türkçeden geçmiş bazı kelimelerde meydana gelen birtakım ses olayları incelenmiştir.

Yeni tespit edilen örnekler üzerinden bulaşma yoluyla türetilmiş kelimeler bu çalışmada incelenecektir. Tespit edilen örneklerde bulaşma yoluyla meydana gelen ses hadiselerinde dört farklı durum söz konusudur:

\subsection{Arap alfabesindeki ya (ي) harfinin farklı okunmasıyla meydana gelen bulaşma olayları}

Arap alfabesinde bulunan (ي) ya harfinin kullanımı iki şekildedir. Birincisi, aslî sesleri karşılayan ya harfi olarak, ikincisi de uzatma harfi olarak kullanımdır. (ي) ya harfinin uzatma harfi olarak kullanılması (ي) ya'dan önceki harfin esreli, (ي) ya'nın ise harekesiz olması durumundadır. (الرَّحيم) er-rahîm örneğinde görüldüğü gibi ya (ي) harfi, harf olarak değil ḥa (ح) harfindeki esre ile verilen /i/ sesini uzatan bir işaret olarak kullanılmıştır. Arapça (خَيَ) hayr kelimesinde ise aslî sesi karşılayan harf olarak kullanılmıştır. Yani Arapçadaki ya (ي) harfi, Türkçenin ses özelliklerine göre, ünsüz okunan ve kendinden önceki esreli ünsüzü uzun olarak okutan olmak üzere iki çeşittir. Türkçenin Arap alfabesi kullandığımız döneminde Arapçadan farklı olarak bu harfin yüklendiği bir görev, Arapçada hareke ile gösterilen $l, i$ ünlülerini karşılamak olmuştur. Bütün bunlardan dolayı Türkçeye Arapça ve Farsçadan giren ve bünyesinde ya (ي) harfi bulunan bazı kelimelerde analojik olarak, yani bulaşma yoluyla farklı okuyuşlar olmuştur. Bu farklı okuyuşların neticesinde, asli dillerinde ünsüz okunması gereken ya (ي) harfini $\imath$, $i$ ünlüsü olarak; kendinden önceki kesreli harfi uzatan med harfini de ünsüz harfmiş gibi okumak şeklinde bir durum ortaya çıkmıştır. Bu ses olaylarının meydana gelme sebebi sadece bahsettiğimiz bulaşma olmayıp başka durumların etkileri de söz konusudur. Bilindiği gibi $y$ sesi inceltici ve daraltıcı tesire sahiptir. Bu tesiri de göz ardı etmemek gerekir.

14 Çebi, "Yabancı Kökenli Bazı Kelimelerde Ses Değişmeleri Üzerine”, 15-17. 
Fakat aşağıda da görüleceği gibi ya (ي) harfinin sebep olduğu ses olayı sadece daralma yönlü olmamıştır. Bunun için öne sürdüğümüz görüşün dikkate alınması gerektiğini düşünüyoruz. ya (ي) harfi ile ilgili meydana gelen bu ses olayını iki alt başlıkta ele alacağız.

\subsection{1. Ünsüz okunması gereken ya (ي) harfinin ünlü okunduğu kelimeler}

a) hırsız (خيرسز): Bu kelime Şemseddin Sami’nin Kamus-1 Türkî’de işaret ettiği gibi Arapça hayr kelimesinden türetilmiş hayırsız kelimesinden başka bir şey değildir. ${ }^{15}$ Arapça hayr kelimesi, Türkçe kelimelerde hece sonunda bulunmaması gereken " $y r$ " çift ünsüzü ile bitmesi sebebiyle Türkçede hayır şekline dönmüştür. Aynı kelimeye olumsuz sıfat isimleri yapan + sIz ekinin eklenmesi ile oluşan bu kelime bahsettiğimiz durumdan dolayı böyle bir ses olayı geçirmiştir. Bu ses olayını geçirirken de ya (ي) harfinin Türkçede $l$, $i$ gibi ünlü sesleri karşılaması böyle bir bulaşmaya sebep olmuştur.

b) hırlı (خيرلي): Bu kelime de yukarıda izahını yaptığgımız hayr kelimesine olumlu sıfatlar yapan $+l I$ ekinin eklenmesi ile oluşmuştur.

Bu kelimelerde meydana gelen ses olayının başlangıcının Eski Anadolu Türkçesine kadar gittiğini tespit ettik. Hırsız kelimesinin bu dönemde karşılığı og $r$, og rru şeklindedir. hırlı kelimesi Süheyl ü Nev-bahar'da 2661. beyitte EAT döneminin özelliklerine göre hırlu şeklinde geçmektedir:

Delüligi cāhil ḥamiyyet șanur / Önegüligi hırlu niyyet șanur. ${ }^{16}$

Üzerinde çalıştığımız Ahmed-i Dai'nin Kitâbü 't-ta 'bîr' inde bu iki kelime yer almamaktadır. Ancak bu kelimelerin kökü olan hayr, Atatürk Kitaplığı nüshasında bir yerde hır olarak

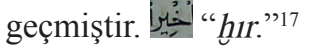

Hırlı için TDK Türkçe Sözlük'te "1. İşinde doğru, uslu, iyi (kimse). 2. Yaramaz, şımarık, kötü (kimse). hırlı mıdır, hırsız mıdır? Bir kimsenin ahlakı kişiliği hakkında kuşku duyulduğunda kullanılan bir söz: Ben onu tanımıyorum; hırlı mıdır hırsız mıdır?" anlamları verilerek örnek bir cümle kurulmuştur. ${ }^{18}$ Hırsız $\boldsymbol{I}$ için ise "Başkasının malını çalan kimse, uğru” karşılıkları verilmiştir. ${ }^{19}$

Bu iki örneğin kökünün yansıma bir kelime olan hır olup olamayacağını da düşündük. Türkçe Sözlük'te hır için kavga, dalaş anlamları verilmektedir. ${ }^{20}$

Hırsız kelimesi için bu kökü, yapılan işin mahiyeti itibarıyla gürültüsüz, sessiz kişi şeklinde bir yere kadar yakıştırabiliriz. Ancak hırlı için bu kökün doğru olmadığını düşünüyoruz. Yani hırlı, hır çıkaran, kavgacı, gürültücü demek değildir. Hırlı Türkçede her ne kadar anlam olarak olumlu ise ve bu anlamı taşıyan bir isim veya sıfat olarak kullanılmasa da olumsuz

15 Çebi, "Yabancı Kökenli Bazı Kelimelerde Ses Değişmeleri Üzerine", 16.

16 Cem Dilçin, Süheyl ü Nevbahar (İnceleme-Metin-Sözlük), (Ankara: Atatürk Kültür Merkezi Yayınları, 1991), 375 .

17 Ahmed-i Dâî, Kitâbü’t-ta'bîr, 137b/4.

18 Türkçe Sözlük, 1093.

19 Türkçe Sözlük, 1094.

20 Türkçe Sözlük, 1093. 
karakterler için bu karakterin zıddını ifade eden bir anlam ifade etmek üzere ve daha çok hırsız ile birlikte ikileme şeklinde kullanılır. Anlam vezni olarak adlandırılan kurama göre hırlı hırsız ikilemesinde hırlı hırsızdan zamanla aynı çağrışımsal özelliği kazanmıştır. ${ }^{21} \mathrm{Bu}$ biçimiyle de tek başına kullanıldığı zaman da "hırlı biri olsa hapse girmezdi" örneğindeki gibi olumlu anlamına rağmen olumsuz çağrışım yapmaktadır. Aynı şekilde hırlı mı hırsız mı ikilemesinde baştan hayırlı mı hayırsız $m \iota$ şeklinde kurulan anlam yapısı zamanla sadece kötü anlamı yüklenmiştir.

Bu iki kelime için de bünyelerinde bulunan y sesinin daraltıcı tesirini gözden kaçırmamak gerekir. Bu şekilde oluşmuş hıyr şekli Doğu Anadolu ağızlarında kullanılmaktadır. Bu kelimeleri de böyle okumak mümkündür. Ancak aynı ses olayına tanık olduğumuz aşağıda vereceğimiz açık heceli örneklerden hareketle hır şeklindeki okuyuşun daha doğru olduğu kanaatindeyiz.

c) şıh: Arapça şeyh (شَنَخْ) kelimesinden değişen ve konuşma dilinde kalan bu kelimede de aynı şekilde ünsüz okunması gereken ya (ي) harfinin ünlü $\imath$ sesiymiş gibi okunması söz konusudur. Çünkü şeyh kelimesi de hece sonunda bulunmaması gereken “ $y h$ ” çift ünsüzünden dolayı Türkçenin ses özelliklerine aykırıdır.

d) nalın: Arapça na'l (نَ) kelimesinin tesniye şekli na 'leynden (نَعْلَيْن) ortaya çıkmış bu kelime hece sonundaki “ $y n$ ” çift ünsüzünden dolayı Türkçenin ses özelliklerine aykırıdır. Bu yüzden bu kelimede de aynı ses olayı ortaya çıkmış, ünsüz okunması gereken ya (ي) harfi $l$ şeklinde ünlü okunmuştur. Bu ses olayının Eski Anadolu Türkçesi Döneminden itibaren gerçekleştiğini biliyoruz. nalın ve bundan türetilen nalıncılık kelimesini üzerinde çalıștığımız Ahmed-i Dâ̂’’nin

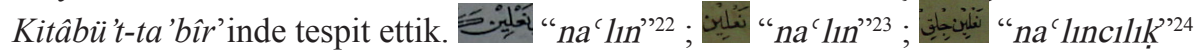

Süleymaniye Hekimoğlu nüshasında Bu örneklerden nalıncılıkta ya (ي) harfi yazılmayıp $\imath$ sesi hareke ile gösterilmiştir: "na'lıncılık"

Ancak örneklerde görüldüğü gibi ayın üzerindeki sükûnu sağlayan cezm işareti bütün örneklerde muhafaza edilmiştir.

e) zeliha (زليخا): Arapça züleyha kelimesi de Türkçeye aynı ses olayı sonucu zeliha şeklinde girmiştir. Bu kelime de Eski Anadolu Türkçesinden itibaren zeliha olarak kullanılmıştır. Kelime bugün Trabzon ağızlarında Zela şeklinde kadın adı olarak kullanılmaktadır.

Aşağıdaki örnekler ise edebi dilde olmayıp Eski Anadolu Türkçesi dönemi ağızlarından birine ait olduğunu düşündüğümüz şekillerdir. Benzer ses olayı geçirmiş kelimeler pek çok ağız bölgesinde mevcuttur. Türkçede e>i daralması sık görülen bir ses olayıdır. Bilhassa $y$ sesinin yanındaki geniş ünlüyü daraltıcı tesiri bilinen bir gerçektir. Bu yüzden aşağıdaki örneklerde ihtiyatlı olmakta fayda mülahaza ediyoruz.

21 Şahru Ufuk Pilten, “Anlam Vezni Kavramı Üzerine Değerlendirmeler”, Avrasya Terim Dergisi, 5 (1) (2017), 2.

22 Ahmed-i Dâî, Kitâbü’t-ta'bîr, Süleymaniye Kütüphanesi Hekimoğlu Ali Paşa, Nr. 588, 193b/2.

23 Ahmed-i Dâi, Kitâbü't-ta'bîr, O.26, 94b/9.

24 Ahmed-i Dâî, Kitâbü't-ta'bîr, O.26, 94b/9.

25 Ahmed-i Dâi, Kitâbü’t-ta'bîr, 588, 101a/3. 
f) bîża /pîżāa (بيذا): Bu kelime Farsça peydâ kelimesinden değişmiştir. Değişme sebebi yukarıdaki örneklerde olduğu gibi sakin okunması gereken ya (ي) harfinin esreli okunmasıdır. Ancak bu peydâ kelimesinin bu şekli yazı diline geçmemiştir. Ahmed-i Dai'nin Kitâbü 't-

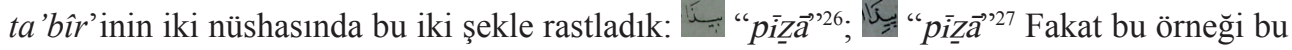
şekli ile Derleme Sözlüğünde tespit edemedik.

g) sîl (سيل): Arapça seyl kelimesi dilimizde sel şekline dönmüştür. Ancak Ahmed-i Dai’nin Kitâbü t-ta 'bîr' inin Atatürk nüshasında bu kelime

\subsection{2. Ünlü okunması gereken ya (ي) harfinin ünsüz okunduğu kelimeler}

Türkçeye Farsçadan geçmiş kelimelerde rastladığımız bu ses olayında ya (ي) harfinin yukarıdaki durumun aksine ünlü olduğu halde ünsüz okunması söz konusudur. Bu şekilde ses olayı geçiren kelimelerimiz şunlardır:

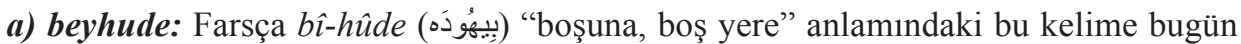
Türkçede beyhude şeklindedir. Kelimenin Eski Anadolu Türkçesi döneminden itibaren bugünkü şekilde kullanılmaya başladığını Ahmed-i Dai'nin Kitâbü 't-ta 'bîr' inde örnekledik. Metinde bu kelime iki defa $b \hat{\imath}$-hûde, iki defa $b \hat{\imath}$-hûźe şeklinde geçerken Atatürk Kütüphanesi nüshasında bir yerde beyhude şeklinde geçmiştir: "us" "beyhüde"29.

b) beynamaz: Farsça bî-namâz (بِينَّاز) "namazsız, namazı olmayan, namaz kılmayan” demek olan bu kelime de bugün Türkçede beynamaz olarak kullanılmaktadır.

c) meyve: Farsça mîve (مِيوَ) meyve kelimesi de Türkçede bugün meyve şeklinde kullanılmaktadır.

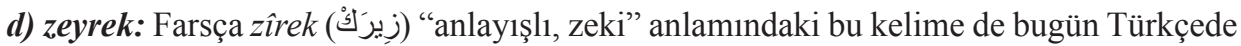
zeyrek şeklinde kullanılmaktadır.

\subsection{Arap alfabesindeki ünsüz okunması gereken vav (و) harfinin ünlü okunmasıyla meydana gelen bulaşma olayları}

Arap alfabesindeki vav (و) harfi de, ya (ب) harfi gibi hem harf hem de uzatma harfi olarak kullanılmaktadır. Örnek olarak vaṣl)(وصل) kelimesindeki vav kelimenin asli harflerinden olan vavdır. mevșūl (موصول) kelimesindeki birinci vav asli harflerden iken ikinci vav ötreli sad harfini $s \hat{u}$ şeklinde uzun okutan uzatma harfidir.

Arap alfabesini kullandığımız dönemde vav (و) harfi, Arapçada olduğu gibi hem /v/ sesini karşılamak için hem de $o, \ddot{o}, u$, $\ddot{u}$ gibi yuvarlak ünlüleri göstermek için kullanılmıştır. Yuvarlak ünlüleri göstermek için Türkçede “ و او, "işaretleri kullanılmıştır. Ünsüzlerin yuvarlak ünlülü okunuşlarını göstermek için de ya ünsüz üzerine ötre işareti konulmuş veya ünsüzden sonra vav (و) getirilmiştir. Yani Arapçada sadece uzatma harfi olarak kullanılan vav (و), Türkçede Arapçadan farklı olarak kısa yuvarlak ünlüler için de kullanılmıştır. İşte aşağıdaki bazı Arapça

26 Ahmed-i Dâi, Kitâbü't-ta'bîr, O.26, 7b/4.

27 Ahmed-i Dâi, Kitâbü't-ta'bîr, 588, 29a/4.

28 Ahmed-i Dâî, Kitâbü't-ta'bîr, O.26, 171a/11.

29 Ahmed-i Dâî, Kitâbü't-ta'bîr, O.26, 156a/1. 
veya Farsça asıllı kelimelerde karşılaştığımız ses olaylarındaki bulaşma sebebi bu olmalıdır. Bu ses olayının tespit ettiğimiz örnekleri şu şekildedir:

a) çorap: Arapça asıll1 cevreb (جَوْرَبْ) kelimesi dilimizde çorap olarak yaşamaktadır. Daha sonra bu değişmiş şeklin Türkçeden Mısır lehçesine ve bazı Arap lehçelerine şurāb şeklinde girdiği tespit edilmiştir. ${ }^{30}$

Bu kelimedeki ses olayının izini Eski Anadolu Türkçesi dönemine kadar takip etmek mümkündür. Üzerinde çalıştığımız Ahmed-i Dai'nin Kitâbü 't-ta 'b̂̂r' inin Hekimoğlu nüshasında üç defa cevreb bir defa çorap şeklinde geçerken Atatürk Kitaplığı nüshasında dört yerde de

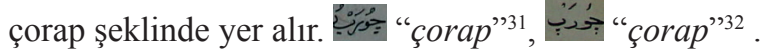

b) musul: Arapça ism-i alet ve ism-i mekân vezni mef'il ile vasala üçlüsünden oluşturulmuş “vasıl olunan yer" anlamındaki mevsıl (َمْوصِلْ kelimesi Irak’ta bir vilayetin adıdır. Türkçede musul şeklinde kullandığımız bu isimde de sakin okunması gereken vav (و) sanki uzatma işaretiymiş gibi kendinden önceki mim harfini yuvarlak ünlülü okutmuştur.

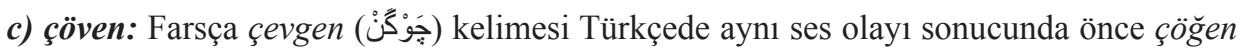
sonra çöven şekline dönüşmüştür. Üzerinde çalıştığımız Ahmed-i Dai'nin Kitâbü 't-ta 'bîr' inde bu kelimede kef, gayın olmuş dolayısıyla kelimenin ünlüleri de kalınlaşmıştır. Hekimoğlu

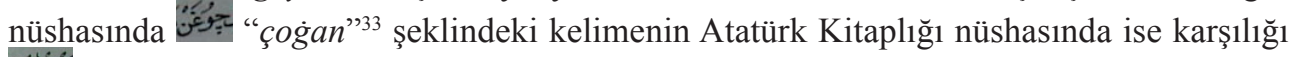

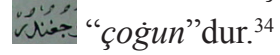

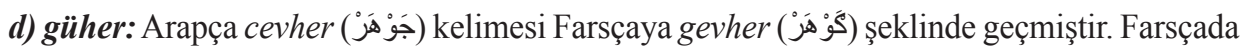

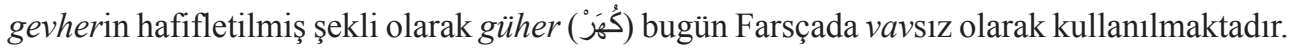
Osmanlı Türkçesinde de kullanılan güher ve bundan türemiş güherlünün vavlı şeklini Ahmed-i Dai'nin Kitâbü 't-ta'bîr'inde tespit ettik:

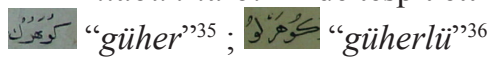

e) sûsen: Arapça sevsen (سَنْسَنْ) “zambak” kelimesi Farsçaya sûsen şeklinde geçmiştir. Yani Farsçada da bu ses olayının aynı şekilde gerçekleştiği görülmektedir. Osmanlı Türkçesine bu kelimenin Arapçadan sevsen şeklinde değil Farsçadan sûsen şeklinde girmiş olması muhtemeldir. Ahmed-i Dai'nin Kitâbü't-ta'bîr'inde bu kelimeyi örnekledik: “'sūsen"37

Çalıştığımız Ahmed-i Dai'nin Kitâbü 't-ta 'bîr' inde bugün edebî dile geçmeyip ağız özellikleri olan kalan bazı örneklere de rastladık. Arapça ve Farsça asılı bu kelimelerde aynı şekilde sakin okunması gereken vav (و) harfi ötreli okunmuştur:

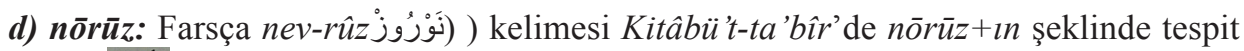

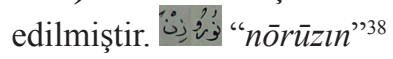

30 Bedrettin Aytaç, Arap Lehçelerindeki Türkçe Kelimeler, (İstanbul: TDAV Yayınları, 1994), 56.

31 Ahmed-i Dâî, Kitâbü't-ta'bîr, 588, 178a/10.

32 Ahmed-i Dâî, Kitâbü't-ta'bîr, O.26, 228b/11.

33 Ahmed-i Dâi, Kitâbü't-ta'bîr, 588, 164a/4.

34 Ahmed-i Dâî, Kitâbü’t-ta'bîr, O.26, 206b/2.

35 Ahmed-i Dâi, Kitâbü't-ta'bîr, O.26, 62b/9.

36 Ahmed-i Dâî, Kitâbü’t-ta'bîr, O.26, 192a/9.

37 Ahmed-i Dâî, Kitâbü't-ta'bîr, 588, 165a/12.

38 Ahmed-i Dâî, Kitâbü't-ta'bîr, O.26, 175b/10-11. 


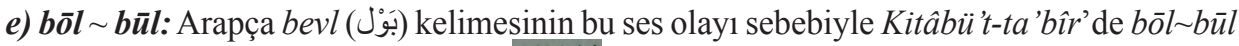
şekline dönmüş örneği tespit edilmiştir.

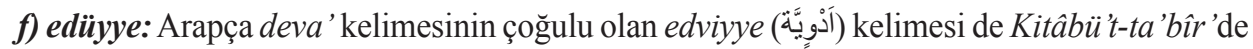
aynı ses olayını geçirmiş ve edüyye şeklinde örneklenmiştir: "edüyye " "400

g) Nüfil: Arapça "güzel yüzlü genç" anlamında olup özel isim olarak kullanılan Nevfel

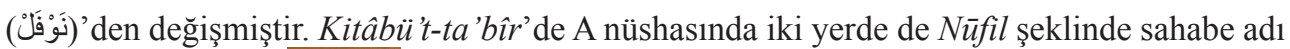

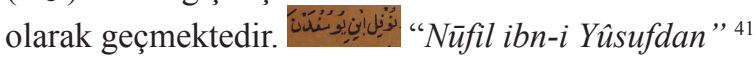

$\mathrm{Bu}$ ses olayına Mısır Kahire ağzında da rastladık. Ancak Mısır Kahire ağzında tespit ettiğimiz ses olaylarında vav (و) uzun ünlü olarak karşımıza çıkmaktadır. Bu örneklerden bazıları şunlardır:

$$
\begin{aligned}
& \text { mûlid < mevlid مَوْلَّ } \\
& \text { loûn > levn لَون (renk) } \\
& \text { fô }<\text { fevk فَوْقَ (üst) } \\
& \text { moûz < mevz مَوْ (muz) }
\end{aligned}
$$

\section{3. kâf-i nûnî ve kâf-i Farisî yerine kâf-i Arabî okunmaktan kaynaklanan ses olayları}

Bilindiği gibi, Osmanlı İmparatorluğu zamanında, Arap alfabesinde bulunmayan $k \hat{a} f-i$ Farisî ve kâf-i nûnî ile karşılanan birtakım seslere sahip kelimelerin imlası Türkçe el yazması eserlerde çoğunlukla kâf-i Arabî iledir. Bu seslere sahip bazı kelimeler, Arap dünyasına çoklukla kâf-i Arabî ile yazılarak taşınmışlardır.

Bu durum aslında, Eski Anadolu Türkçesi döneminde "kişi gişi, küçük güçük, kimse gimse" şeklinde ikili okunan bazı Türkçe kelimelerin transkripsiyonunda da bir problemdir.

\subsection{1. kâf-i nûnî yerine $k \hat{a} f-i$ Arabî okunmaktan kaynaklanan ses olayları}

Arapçanın Mısır lehçesinde zikredilen sesleri taşıyan kelimelerin tamamı kâf-i Arabî ile okunmuştur. Mısır lehçesinde, aşağıdaki Türkçe ve Farsça asıllı kelimelerin telaffuzunda bulaşma yoluyla bazı ses olayları olmuştur. Aslı damak n'si ile olup kâf-i Arabî okunan kelimeler:

a) inkişâri: Türkçe yeñiçeri (يَكِي جَرِي) kelimesi bünyesinde bulunan kâf-i nûnî ile yazılan damak n'sinin Mısır lehçesinde kâf-i Arabî ile yazılması sebebiyle inkişâri şekline dönüştürülmüştür. Kelimedeki ç sesi de birçok Arap lehçesinde olduğu gibi ş sesine dönüşmüştür.

b) bikbâşi: Türkçe askeri rütbe adı olan biñbaşı (بِكَبَانثي) kelimesinde Misır lehçesinde bulaşma yoluyla iki ses hadisesi olmuştur. Bunlardan birincisi damak n'sinin kef olarak okunarak $/ k$ / sesine dönüşmesi, ikincisi de Türkçede /a/ sesini karşılayan elif harfi uzatma işareti gibi yorumlanarak uzun a olarak okunmasıdır. Yani Türkçe biñbaşı kelimesi Mısır lehçesinde bikbâşı şekline dönüşmüştür.

39 Ahmed-i Dâî, Kitâbü't-ta'bîr, O.26, 70b/2.

40 Ahmed-i Dâi, Kitâbü't-ta'bîr, 588, 62a/12.

41 Ahmed-i Dâî, Kitâbü’t-ta'bîr, O.26, 119a/6. 


\subsection{2. kâf-i Farsî yerine kâf-i Arabî okunmaktan kaynaklanan ses olayları}

c) bek: beğ (بَحَ) Bugün Türkiye Türkçesinde bey olarak telaffuz edilen bu kelime Misır lehçesinde bek şeklinde telaffuz edilmektedir.

d) yeken: yeğen: (يَكَّن Bu kelime de Misır lehçesinde / $k$ / ünsüzü ile söylenir.

e) lakan: Farsça asıllı legen (لَنَنْ) Osmanlıca döneminde Arapçanın Lübnan ve Suriye lehçelerine lakan şeklinde girmiştir. ${ }^{42}$

\subsection{Harekeleme farklılığından kaynaklanan bulaşma örnekleri}

Buradaki durum Arap alfabesi ile yazılan bir kelimede bazı harflerin farklı harekelenmesidir. Bu ses olayının görüldüğü iki örnekte de dikkat çeken şey bu harekeleme farklılığının yanlışlıkla yapılmış olmamasıdır. Çünkü bu farklı harekeleme sonucunda ortaya çıkan kelimeler ile karşıladığı nesneler arasında kuvvetli bir anlam ilişkisi mevcuttur. Bunun için bu kelimelerde rastladığımız ses olaylarının birer yanılgı olmayıp yakıştırma olduğunu düşünüyoruz. Bu kelimelerde ortaya çıkan ses olayında o kelimelere yüklenen anlam etkilidir.

a) elçi ibik < alaca ibik

Örneklerimizden biri Eski Anadolu Türkçesi döneminde hüthüt, çavuş kuşu karşılığında kullanılan alaca ibik kelimesinden değişmiş elçi ibiktir. Ahmed-i Dai'nin Kitâbü 't-ta 'bîr' inde Atatürk Kitaplığı nüshasında bir yerde bu örneğe rastlanmıştır. Eserin diğer nüshası Hekimoğlu Ali Paşa'da kelime alaca ibik şeklindedir. Bu kelimede meydana gelen bulaşma çok ilginçtir. Hüthüt kuşunun Süleyman peygambere (a.s.) elçilik yapması bizce bu bulaşmada rol oynamıştır. Ancak ses olayının meydana geliş şekli, aynı harflerin farklı harekelenmesi suretiyle olmuştur.

Bugün bu kelime Vezirköprü-Samsun ağzında Eski Anadolu Türkçesinde de kullanıldığı gibi sadece $i b i k$ şeklinde kullanılmaktadır. Samsun-Çarşamba ve köyleri ile Sivas-Koyulhisar'da ibik kelimesi bu manaya yakın olarak "söz götürüp getiren, dedikoducu" anlamında kullanılmaktadır. ${ }^{43}$

"elçi ibik" ;

b) ip odunluğu $<$ ip avadanlı̆̆

Bu kelime kilim ve kumaş tezgâhlarında iplerin sarıldığı kütük için kullanılmaktadır. İp odunluğu şekli Kitâbü't-ta'bîr'in Atatürk kitaplığı nüshasında bir yerde geçmiştir. Hekimoğlu Ali Paşa ve Atatürk nüshasında bir başka yerde kelime ip avadanlığ s şeklinde geçer. Bu örnekte de ip sarılan kütüklerin odundan olması bulaşmada anlam etkisi yapmıştır. Ancak aşağıda örneklerde görüldüğü gibi kelimelerin harfleri aynı harekelenmesi farklıdır.

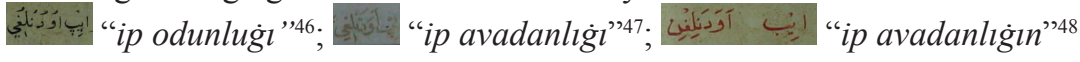

42 Bedrettin Aytaç, Arap Lehçelerindeki Türkçe Kelimeler, 97.

43 Derleme Sözlüğü, (Ankara: TDK Yayınları, 1974), C. 7, 2502.

44 Ahmed-i Dâi, Kitâbü't-ta'bîr, O.26, 83b/9.

45 Ahmed-i Dâî, Kitâbü’t-ta'bîr, 588, 90a/2.

46 Ahmed-i Dâî, Kitâbü’t-ta'bîr, O.26, 103b/8.

47 Ahmed-i Dâî, Kitâbü’t-ta'bîr, 588, 106b/13.

48 Ahmed-i Dâî, Kitâbü’t-ta'bîr, O.26, 103b/6. 


\section{Sonuç ve Öneriler}

Yukarıda verdiğimiz örneklerde görüldüğü gibi Türkçeye Arapça ve Farsçadan giren bazı kelimelerde Arap alfabesini kullandığımız devrelerde meydana gelen bazı ses olaylarının sebebi bulaşmadır. Bulaşmanın sebebi de Arap alfabesidir. Arap alfabesindeki farklı okunuşa sahip bazı harflerin Arapçada kullanıldıkları asıl şekilleriyle değil de diğer şekliyle okunmasından kaynaklanan bu ses olayı sadece Türkçede karşılaştı̆̆ımız bir olay değildir. Bulaşma kaynaklı bu ses olayı, Arapçanın bazı lehçelerinde ve Farsçada da bu durumdan kaynaklanan iki şekilli bazı kelimelerin oluşmasına sebep olmuştur. Yine Arap alfabesinde kullanılan hareke sisteminden kaynaklanan bulaşma sonucu bir kelimenin aynı harflerle fakat farklı harekelerle yazılmış ikinci şekline de rastlanmıştır.

Bilhassa Eski Anadolu Türkçesi dönemine ait eserlerin bu bakış açısıyla incelenmesi ve Tarama Sözlügüü ile karşılaştırmalı bir çalışma yapılması bu örneklerin sayısını artıracaktır.

$\mathrm{Bu}$ çalışma, ses olaylarının önce konuşma dilinde meydana gelip sonra bunların bir kısmının yazıya geçmesi ilkesinin yanında, yazının ses olayına sebep olduğuna dair örneklerin hiç de az olmadığını ortaya koymaktadır.

$\mathrm{Bu}$ çalışmada ortaya konulan örneklerin, Türkçenin etimolojik sözlüğüne de katkı sağlayacağı umulmaktadir.

Hakem Değerlendirmesi: Dış bağımsız.

Çıkar Çatışması: Yazar çıkar çatışması bildirmemiştir.

Finansal Destek: Yazar bu çalışma için finansal destek almadığını beyan etmiştir.

Peer-review: Externally peer-reviewed.

Conflict of Interest: The author has no conflict of interest to declare.

Grant Support: The author declared that this study has received no financial support.

\section{Kaynaklar/References}

Ahmed-i Dai, Kitābü 't-ta'bir, Süleymaniye Kütüphanesi Hekimoğlu Ali Paşa Nr. 588.

Ahmed-i Dai, Kitābü 't-ta'bir, Atatürk Kitaplığı (İstanbul Belediye Kütüphanesi) Muallim Cevdet Nr. O.26.

Aytaç, Bedrettin. Arap Lehçelerindeki Türkçe Kelimeler, İstanbul, TDAV Yayınları, 1994.

Böler, Tuncay. “Dilbilgisi Çalışmalarında 'Karışma, Karıştırılma, Yanlış Hece Bölünmesi, Yanlış Çözümleme'

Gibi İfadelerle Açıklanan Bulaşma (contamination) Örnekleri Üzerine”, (BILMES 2017) (I. Uluslararası Bilimsel ve Mesleki Çalışmalar Sempozyumu) (2017): 905-914.

Çebi, İhsan Sabri. "Yabancı Kökenli Bazı Kelimelerdeki Ses Değişmeleri üzerine”, Türk Dili, 547, (1997) : 15-17.

Çebi, İhsan Sabri. “Arap Alfabesindeki (ي, و ( Harflerinin Osmanlıcadaki Bazı Arapça ve Farsça; Osmanlı

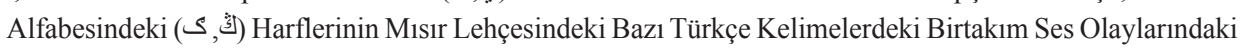
Rolü”, المؤتمر الدولي الترجمة ودورها في تفاعل الحضارات Sempozyumu Bildiri Kitab1, Kahire, (1998): 2844-2849.

Derleme Sözlüğü, Ankara: TDK Yayınları, 1997. 
Dilçin, Cem. Süheyl ü Nev-bahar (İnceleme-Metin-Sözlük), Ankara: Atatürk Kültür Merkezi Yayınları, 1991. Ercilasun, Ahmet Bican. Üniversiteler İçin Türk Dili Dersleri, Ankara: Yök Yayınları, 1992.

Ercilasun, Ahmet Bican. Türkiye Türkçesinde Yardımcı Ses, Türk Dili Dil ve Edebiyat Dergisi Eylül 2000, 585, 2000/II, 219-225.

Ercilasun, Ahmet Bican. "Oğuz Adının Etimolojisi”, Oğuzlar: Dilleri, Tarihleri ve Kültürleri, 5. Uluslararası Türkiyat Araştırmaları Sempozyumu, (2015): 15-20.

Ergin, Muharrem. Türk Dil Bilgisi, İstanbul: Bayrak Yayınları, 2013.

Kara, Mehmet. Ayrı Düşmüş Kelimeler, İstanbul: Kesit Yayınları, 2011.

Karaağaç, Günay. Türkçenin Ses Bilgisi, İstanbul: Kesit Yayınları, 2010.

Pilten Ufuk, Şahru. “Anlam Vezni Kavramı Üzerine Değerlendirmeler”, Avrasya Terim Dergisi, 5 (1), (2017): 1-10.

Şemsettin Sami, Kamus-ı Türki, İstanbul: Çağrı Yayınları, 2010.

Türkçe Sözlük, Ankara: TDK Yayınları, 2011.

Vardar, Berke. Dilbilim ve Dilbilgisi Terimleri Sözlüğ̈̈, Ankara: TDK Yayınları, 1980. 
